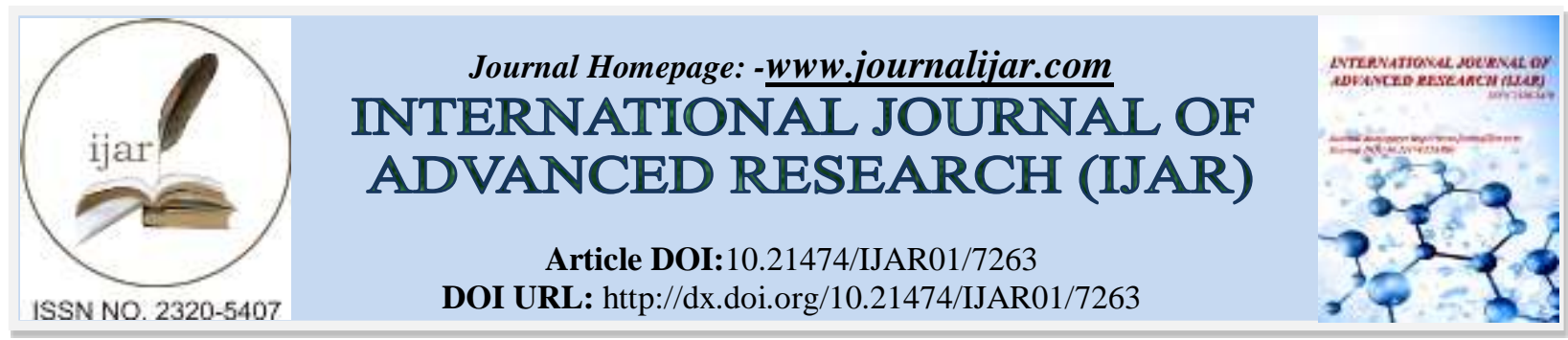

RESEARCH ARTICLE

\title{
OIL REVENUE MANAGEMENT FOR INFLATION CONTROL IN NIGERIA: A VECTOR AUTOREGRESSIVE (VAR) ANALYSIS APPROACH.
}

\author{
Igwe Ikechukwu ${ }^{1}$, Obindah Gershon, Ph. ${ }^{2}$ and Omowumi Iledare, Ph.D. ${ }^{3}$ \\ 1. Emerald Energy Institute, University of Port Harcourt, Nigeria. \\ 2. Covenant University, Ota, Ogun State, Nigeria. \\ 3. Emerald Energy Institute, University of Port Harcourt, Nigeria.
}

\section{Manuscript Info}

Manuscript History

Received: 11 April 2018

Final Accepted: 13 May 2018

Published: June 2018

Keywords:-

Nigeria, oil revenue, inflation and vector autoregression.

\begin{abstract}
Nigeria has experienced fluctuations in oil revenue in recent years, this has reflected in a rise in inflation, exchange rate appreciation and consequently weak economic growth. This paper examined the impact of oil revenues on inflation in Nigeria from 1970 to 2015 using econometric techniques of vector autoregressive (VAR) model. The pre-estimation, tests (unit root and cointegration) informed the researcher's decision to estimate a vector error correction mechanism. The estimated VECM model shows that inflation and gross national savings will react against the error with adjustable speed of $30.90 \%$. Secondly, the coefficient of one-year lag of oil revenue appeared with the expected negative sign but not significant. A significant transmission mechanism from oil revenue to government spending and to inflation was also not observed from the result. The impulse response result shows that a unit positive standard deviation shock to oil revenue will lead to a positive response from inflation from the first year till the tenth year. Moreover, the controlling variables show a negative response from year one to the tenth year. The variance decomposition result shows that a shock in oil revenue will account for an average of $18.90 \%$ variation in inflation, moreover, a shock in government total expenditure and gross national savings will account for an average of $8.40 \%$ and $1.07 \%$ variation in inflation during a 10year period respectively. This study concludes that oil revenue has a positive impact on inflation, whereas government expenditure and national savings would reduce inflation growth. This suggests that fiscal policy in the form of increase government expenditure and savings should be implemented to stabilize the economy and reduce inflation.

Copy Right, IJAR, 2018,. All rights reserved.
\end{abstract}

\section{Introduction:-}

Since the discovery of hydrocarbon, crude oil revenue has remained the major source of income in Nigeria economy. Oil revenue accounts for 85 percent of export revenues and 69 percent of total income generated (CBN, 2017). Up until, the early 1970s, crude oil revenue was fluctuating as a result of the oil price decline to $\$ 3.00$ per barrel. However, a windfall price occurred from early 1970s to early 1980s, which was driven by disruptions in the 
supply of oil from the Middle East, which led to a rise in the oil price at the pick level of $106.36 \$$ per barrel in 1980. The subsequent years from 1981, witnessed the oil price decline and revenue drop which continued for a long period from 1981 to 1989 (CBN, 2013). The price decline and revenue shortfall was attributed to lower oil demand, due to the economic meltdown in most industrialized nations in addition to the adoption of more energy-efficient technology. Although, the windfall period led to an era of prosperity, however, it encourages the neglect of other sectors such as agriculture, solid mineral and manufacturing which reflected in inflation rise, exchange rate appreciation and import subsidies.

From 2012, oil revenue suffered from continuous decline, the nation's crude oil revenue dropped from $\$ 94.6$ million it recorded in 2012 to $\$ 89.3$ million in 2013 and \$76.9 million in 2014 (OPEC, 2014). Nigeria monthly crude oil earnings for 2015 was on the decline, specifically, at N286.24 billion. Oil receipts, which constitutes 38.9 percent of the nation's total revenue, were lower than the receipt in her previous month and the corresponding period of 2014, by 21.5 and 54.0 per cent respectively (CBN, 2015). The estimated federally collected revenue of N735.07 billion, in April 2015 was lower than the monthly budget estimate by 9.8 percent (CBN, 2016). The decline in the estimated federally collected revenue relative to the monthly budget estimate was due to the shortfall from oil revenue during the month of April. The economic condition in Nigeria throughout this period mirrors to the trend in global oil prices and consequently oil revenue shortfall in Nigeria. Fluctuation in oil revenue has been argued to contribute to inflation growth in Nigeria. This is because fiscal policies in Nigeria are vulnerable to global oil prices leading to a dip in government revenue and consequently inflation and economic decline.

Inflation is the persistent increase in the costs of products and services cause by an upsurge in the aggregate money supply for a long duration (Jhingan, 2002). It is an economic condition where in the same economy the increase in money supply is higher than the production of goods and services (Hamilton, 2001). Excessive growth in money supply is responsible for high rates of inflation (Barro and Grilli, 1994). It leads to rise in transportation costs, food stuffs, services and exchange rate. Besides, inflation makes it difficult for a nation's currency to serve as a medium of exchange void of adversely affecting output, employment and income distribution (CBN, 1984). Essentially, inflation is better described as a condition that generates uncertainty in the future, whereby a fall in the worth of the nation's currency and an ascent in her exchange rate with other country's currency. This is obvious on account of the worth of the Naira (N), which was N1 to \$1 (one US Dollar) in 1981, normal of N100 of \$1 in year 2000 (Okeke, 2000), N128 to $\$ 1$ in 2003 and over N 363 to $\$ 1$ in 2017 (CBN, 2017). This decrease in the worth of the Naira corresponds to the era of inflation growth in Nigeria, and is an unpleasant occurrence that has prompted a decrease in the welfare of ordinary Nigerian citizens. Fluctuation in oil revenue could have considerable impact on the stability of major macroeconomic variables in Nigeria. It may lead to a shortfall in government expenditure and national savings: which may adversely affect productivity, unemployment, and inflation, hence the need for a diversified economy is required. Herein lies the need for this study to examine the effect of oil revenue fluctuation on inflation growth in Nigeria.

\section{Statement of the Problem:-}

From the time of oil windfall of 1970's, inflation rate in Nigeria has been unstable, ascending more than 35 percent in 2003 (CBN, 2008). This has been ascribed to the upsurge in money supply and some policy changes, for example, supply shocks emerging from the oil price, extreme oil revenue flow and wage rate increment base on the Udoji commission of the 1974 proposal. The changes prompted an increase in the deficit and ascend in money in circulation to about 70 percent that affected domestic credit to the private sector of the economy (CBN, 2006). In order to check inflationary growth, fiscal rules have been applied by the government to limit the structural budget deficit through the containment of fiscal spending, saving of some proportion of the oil revenue windfall. Investment in human capital not only to increase efficiency of labour, but to promote economic stability has also been adopted (Barro, 1997). Unfortunately, the shortfall in crude oil revenue, rise in inflation rate and slowdown in economic growth, is an indication that much success have not been recorded.

Recent empirical studies have revealed different deductions on the effect of oil revenue on inflation in Nigeria. Some are of the conclusion that oil revenue adds to inflationary growth, while some contend on the contrary. Hamilton (2011) attests that inflationary growth were caused by higher revenue from an ascent in the crude oil price. Katsuya (2008) findings demonstrate that inflation rise by 0.36 percent as oil price ascend by 1 percent. Farzanegan and Markwardt (2009) reveals that both positive and negative oil price shocks raise inflation considerably. Eltejaei and Afzali (2012) demonstrates that instability in oil price and oil revenue cause inflation as government current and capital spending take disproportionate reaction to both negative and positive shocks. The country's oil revenue 
decrease from $\$ 94.6$ million it recorded in 2012 to $\$ 89.3$ million in 2013 and $\$ 76.9$ million in 2014. Nigeria monthly oil revenue for 2015 was on the decrease, precisely, at N286.24 billion (CBN, 2015). Oil receipts, which constitutes 38.9 percent of the country's aggregate income, were lower than the receipt in her previous month and the comparable period of 2014, by 21.5 and 54.0 for each percent correspondingly (CBN, 2015). The implication of the oil revenue fluctuation calls for the need to investigate the impact on inflation growth in Nigeria. The main aim of this study is to examine the relationship between crude oil revenue and inflation in Nigeria. Hence the following objectives would be achieved by this paper:

An examination of the impact of oil revenue on inflation control in Nigeria A determination of the nature of causality between oil revenue and inflation in Nigeria An investigation of the extent to which oil revenue can forecast inflation in Nigeria.

The following null hypotheses were also tested:

$\mathrm{H}_{0}$ : Oil revenue has no significant impact on inflation

$\mathrm{H}_{0}$ : There is no significant causality between oil revenue and inflation

$\mathrm{H}_{0}$ : Oil revenue did not significantly forecast inflation in Nigeria

\section{Significance of the Study:-}

This study is undertaken with a view of ascertaining the impact of oil revenue on inflation control in Nigeria. The study addresses how government and households respond to macroeconomic imbalance in the economy during the period of inflation. The study would add to existing literature on oil revenue and inflationary trend in Nigeria. Thus, providing much information to future empirical studies. The study is also timely in view of the inflation growth in Nigeria caused by volatility of oil prices and shortfall in oil revenue. The study will help in the formulation of policies to encourage additional revenue generation, diversification, savings of oil revenue windfalls and prudent expenditure.

\section{Literature Review:-} Theoretical Review:-

In order to analyse how the management of oil revenue affects inflation growth in Nigeria, this study employs different theories of inflation to support this research. These are; the monetarist theory, the quantity theory of money, the structuralism theory and the classical theory. The classical theory of inflation is founded on the classical quantity theory of money. According to Fisher (1911) inflation occurs in direct proportion to rise in money supply, given the range of output. This theory is derived from the classical quantity theory of money, which affirms that inflation is cursed by an extreme upsurge in the amount of money available for use. To be more precise, the classical theory clarifies how the total price level gets decided through the association between money supply and money demand.

The monetarist theory of inflation identifies with Friedman (1963), who pioneer the classical monetary theory of money. He opines that price level ascents with a proportionate rise in the supply of money in an adjusted method. He further argues that inflation is an occurrence that is all the times everywhere, a monetary occurrence can be created all the more quickly with a rise in the amount of money than the increment in output. In spite of the fact that, he accepts that prices ascend because of the increase in money, such increment isn't proportionate. The monetarist way to deal with inflation has its premise in the quantity theory of money. This is founded largely with respect to two presumptions relating to money, viz. exogeneity of money supply and neutrality of money. Moreover, Campos (1961) and Friedman (1963) recommends that the direction of causality moves from money supply to the price level. The vital deduction suggests that the effect of changes in money supply is as a reflection of changes in the price level in the economy.

The quantity theory of money, refers to the equal relationship between national income estimated at market prices and the velocity of circulation of the money supply. Based on this theory, there is a positive relationship between price levels and the money supply. Therefore, there will be a balanced, positive relationship between the money supply and the price levels of a given economy. That is, when the money supply increases by a certain percentage the price levels will also increase by an equal percentage. Thus, this theory believes that inflation is caused by an expansion in the money supply of a given economy (Ricardo, 1817). It is under the idea that inflationary situations arises due to an increase in money supply which is not followed by, or supported by an increase in output levels of an economy (Wesley, 1896). 
Structuralism theory states that the main reason for inflation is the inelasticity in the structures of the economy. This theory is mainly used to explain the nature and basis of inflation in developing countries. The theory states that the inflation rates in developing countries are affected by the inelasticity of the following factors; production level and capacity, capital formulation, institutional framework, high inelasticity in the agricultural sector, inelasticity of the labour force and employment structures (McCallum, 1987). This inflation, giving the structural improvement, results at a cost that is given for immediate economic growth. The structuralism school suggests that inflation is a natural outcome of rapid economic development and growth process and results primarily from non-monetary factors. The early contributors to the idea of structuralism among many others were Noyola (1956), Sunkel (1960), Olivera (1964) and Chenery (1975). These economists argued that at times of rapid economic development and growth, the aggregate demand in the economy rises, however the supply in the economy does not rise at the same rate as a rise in demand due to the existence of structural bottlenecks. The gap between aggregate demand and supply created by the presence of the bottlenecks leads to inflationary pressures in the economy (Amdt, 1985).

\section{Empirical Review:-}

Few studies have looked at the impact of oil revenue on inflation growth in Nigerian. This paper intends to fill in the gap by investigating the relationship between crude oil revenue and inflation rate in Nigeria. Previous research contributions have shown lack of consensus on the topic. This empirical review captures both views with the aim of making a broader contribution to existing literatures. Apere (2017), utilizing a vector autoregressive model examined the connection between oil price fluctuations and inflation in Nigeria base on quarterly data from 1980 to 2015. The study result shows that a steady negative inflation rate is caused by a steady and positive oil price and that inflation contracts as oil price declines.

Umar, Aliyu and Ahmad (2017) applying vector autoregression VAR show the connection between oil price and economic growth in Nigeria from 1974-2014. A long-run relationship does not exist among the variables as uncover by the analysis. In any case, the Granger causality test demonstrates that there is a significant unidirectional causality running from oil price to economic growth in the short run. Moreover, there is a significant positive unidirectional causality running from oil price to total exports and human capital to economic growth in Nigeria.

Brini, Haterm and Arafet (2016) utilizing a Structural VAR model to analyse the effect of oil price on inflation and the exchange rate in six oil exporters and importers MENA nations: Tunisia, Morocco, Algeria, Bahrain, Saudi Arabia and Iran. The impulse response function result means that in the long run, oil price volatility has a significant effect on exchange rate of the oil-importing nations of Tunisia and Morocco. However, the effect on inflation is lesser and consumed by the inflexible nature of the subsidized product prices. The variance decomposition additionally, reveals that oil price shocks do not explain, especially the variation in the two deliberated variables Algeria and Iran.

Tural et al (2016), look at the oil pass through into inflation: evidence of oil exporting nations of Russia, Azerbaijan and Kazakhstan. They utilize vector autoregrssion model VAR. The empirical result demonstrates that the level of inflation in these oil-exporting nations, reacts significantly to oil price shocks. The major contributor to the impacts of oil price shocks on inflation are fiscal and cost channels. The paper provides imperative policy implications in ensuring price stability of Central Banks, by giving new confirmation from emerging oil-exporting nations.

Imene and Farid (2016) investigate the impact of real oil revenue fluctuations on economic growth in Algeria from 1960 to 2015. They apply the Johansen multivariate cointegration approach to analyse the short-run and the long-run dynamic relationship between real oil revenues and economic growth proxy by two variables, namely, real GDP and industrial sector growth. The cointegration analysis suggests that a long-run relationship exists between real oil revenues, real GDP, and industrial growth in Algeria. The impulse response function and the variance decomposition demonstrate that the impact of unexpected shifts in real oil revenues on the country's economic and industrial growth is negative.

Nwanne and Eyedayi (2016) utilizing multiple regressions as a tool for data analysis investigates the impact of crude oil price volatility on economic growth of Nigeria from 1980 to 2014. The findings revealed that there is a positive and significant relationship between oil price and economic growth. Based on the findings the researchers conclude that oil price volatility does not have a positive impact on the economy, contrary to the findings of some earlier studies but oil price itself does. 
Kamyar and Yousef (2015), look at the Granger causality of inflation rate, oil income and taxation in Iran. Oil and tax are chosen as two intermediaries of income sources. The outcome from granger causality test in light of Vector Error Correction Model (VECM) shows positive unidirectional causality from oil income and corporate tax with price level and negative unidirectional income tax and price level in the long run. The Granger causality test in view of VAR test indicates that there is basically significant unidirectional in oil income and price level in the short run.

Akinleye and Ekpo (2013) examine the macroeconomic ramifications of oil price shocks on macroeconomic performance in Nigeria. The study utilized the vector autoregressive estimation procedure and reveal that both positive and negative oil price shocks impact real government spending just in the long run instead of in the short run. It also found that the more positive rather than negative oil price shocks have stronger short and long run effects on real gross domestic product, thereby triggering inflationary pressure and domestic currency depreciation in the process as importation increases. The study posits that crude oil price shocks are capable of impeding economic growth only in the long run while raising prices level marginally in the short run leading to exchange rate depreciation and high importation.

Oriakhi and Iyoha (2013), analyze the outcomes of oil price instability on the growth of the Nigerian economy from 1970 to 2010. Utilizing a VAR system, the investigation uncovers that from the six variables tested, instability in oil price affected specifically on real exchange rate, real government spending and real import. Be that as it may, affected on real money supply, genuine GDP and inflation through other variables, especially real government spending. This infers oil price uncertainty, decides government spending level, which in line decides the growth of the Nigerian economy.

Kamyar (2013) researches the connection between inflation rate, oil revenue and taxation in IRAN. The Ordinary Least Square (OLS) was utilized as a technique for data analysis in the short and long run periods. The investigation uncovers that oil revenue and corporate tax are significant variables to estimation of consumer price index. Taxation has both positive and negative effects on economic growth and consumer price index because of expanding and diminishing inflation rate.

Eltejaei and Afzali (2012) look at the effect of oil revenue changes in some macroeconomics variables in the Iranian economy from 1990 to 2008. The outcome uncovers that positive shocks prompt economic growth. The assessed result, likewise demonstrates that volatility in oil prices and oil revenue is the reason for inflation, government present and capital spending take unequal reaction to both negative and positive shocks.

Sweidan (2004) analysed the connection amongst inflation and economic growth of Jordan utilizing a non-linear model and found a structural break point at the two percent level of inflation. The investigation was also to check the impact of the inflation vulnerability on the development and improvement of the economy. The outcome uncovers that the impacts of inflation on growth were more grounded when contrasted with the impacts of inflation vulnerability and fluctuation.

\section{Research Method:-}

Methodology for the Study:-

The analysis is based on the econometric tools, utilizing various model approaches such as research design, sources of data collection, strategy of the investigation and methods of data analysis, VAR specification, unit root, cointegration, impulse response shock approach to the study, Vector Error Correction Mechanism (VECM) and Causality test. Study aims is to estimate the dynamic relationship between oil revenue and inflation in Nigeria.

\section{Research Design:-}

The quantitative research design was adopted for the study. Specifically, the analysis of data was done using the econometric quantitative approach and interpretation done accordingly.

\section{Data Collection Source:-}

This study employed annual time series data from 1970 to 2015. The data were obtained mainly from Central Bank of Nigeria Statistical Bulletin, EIA, World Bank, BP statistics and IMF. Variables for which data were collected are; crude oil revenue Oil (OREV), government total expenditure (TGEXP), national savings (NSAV) and an inflation rate (INFL). 


\section{Econometric Technique:-}

The Vector auto-regression (VAR) model was adopted as the key model for this work to identify the movement and the relationship between all the variables in the VAR model are treated symmetrically by including for each variable and equation explaining its evolution based on its own lags and the lags of all the other variables in the model. To estimate the model, some tests were carried out which included: Test for stationarity (unit root test), cointegration, VAR estimate test, Granger causality test, impulse response function test and forecast error variance decomposition test.

\section{Model Specification:-}

For the purpose of analysing and forecasting macroeconomic activities, and tracing the relationship between oil revenue and inflation rate in Nigeria economy, VAR models in addition to forecasting have been used to serve two primary functions: testing causality and studying the effects of shocks through impulse response characterization and forecast error variance decomposition. This study, therefore, estimated a vector autoregressive (VAR) model to trace the effect of crude oil revenue fluctuation on inflation growth in Nigeria. We specified the generalized VAR model as:

$\mathrm{Y}=\Pi_{0}+\Pi_{1} \mathrm{X} 1+\Pi_{2} \mathrm{X} 2+\Pi_{3} \mathrm{X} 3+---+\Pi_{\mathrm{n}} \mathrm{Xn}$. .1

Where; $\mathrm{Y}=$ dependent variable, $\Pi_{0}=$ intercept term, $\Pi_{1}, \Pi_{2}, \Pi_{3},---\Pi_{n}=$ regression coefficients to be determined, $\mathrm{X} 1, \mathrm{X} 2, \mathrm{X} 3 \ldots \ldots \mathrm{Xn}=$ set of explanatory variables. We re-specify the model to capture the objectives of our study.

$$
\text { IFR }_{\mathrm{t}}=\Pi_{0}+\Pi_{1} \mathrm{OREV}_{\mathrm{t}}+\Pi_{2} \mathrm{TGXP}_{\mathrm{t}}+\Pi_{3} \mathrm{NSAV}_{\mathrm{t}}+\varepsilon_{\mathrm{t}} ; \mathrm{t}=1,2, \ldots . \mathrm{n}
$$

Where; $\mathrm{IFR}_{\mathrm{t}}=$ Inflationary Rate (dependent variable), $\mathrm{OREV}_{\mathrm{t}}=$ Oil Revenue, $\mathrm{TGXP}_{\mathrm{t}}=$ Total Government Expenditure, $\mathrm{NSAV}_{\mathrm{t}}=$ National Savings and $\varepsilon_{\mathrm{t}}=$ Error term.

Where; $\Pi_{0}, \Pi_{1}, \Pi_{2}$ and $\Pi_{3}$ denote respectively the unknown intercept and slope parameters to be estimated and $\varepsilon_{t}$ is the disturbance term assumed to be purely random. The vector autoregressive (VAR) model is a flexible model for the analysis of multivariate time series and it is particularly useful for describing the dynamic behaviour of macroeconomic time series (Juselius, 2006). Because of these characteristics, the VAR and the vector error correction model (VECM) approaches have been widely used in the literature.

\section{Inflation rate (INFL) VAR Model Specification:-}

$$
\begin{aligned}
& L \operatorname{Lg}(I N F L)_{t}=c_{1}+\sum_{i=1}^{p} \pi_{11}^{i} \log (I N F L)_{t-i}+\sum_{j=1}^{p} \pi_{12}^{j} L \operatorname{og}(\text { OREV })_{t-j}+\sum_{k=1}^{p} \pi_{13}^{k} \log (T G E X)_{t-k}+\sum_{l=1}^{p} \pi_{14}^{k} \log (G S A V)_{t-l}+\varepsilon_{1 t} \\
& \log (\text { OREV })_{t}=c_{1}+\sum_{i=1}^{p} \pi_{21}^{i} \log (I N F L)_{t-i}+\sum_{j=1}^{p} \pi_{22}^{j} \log (\text { OREV })_{t-j}+\sum_{k=1}^{p} \pi_{23}^{k} \log (\text { TGEX })_{t-k}+\sum_{l=1}^{p} \pi_{24}^{k} \log (G S A V)_{t-l}+\varepsilon_{2 t} \\
& \log (\text { TGEX })_{t}=c_{1}+\sum_{i=1}^{p} \pi_{31}^{i} \log (\text { INFL })_{t-i}+\sum_{j=1}^{p} \pi_{32}^{j} \log (\text { OREV })_{t-j}+\sum_{k=1}^{p} \pi_{33}^{k} \log (\text { TGEX })_{t-k}+\sum_{l=1}^{p} \pi_{34}^{k} \log (G S A V)_{t-l}+\varepsilon_{3 t} \\
& L \operatorname{og}(G S A V)_{t}=c_{1}+\sum_{i=1}^{p} \pi_{41}^{i} \log (I N F L)_{t-i}+\sum_{j=1}^{p} \pi_{42}^{j} L \operatorname{og}(\text { OREV })_{t-j}+\sum_{k=1}^{p} \pi_{43}^{k} \log (T G E X)_{t-k}+\sum_{l=1}^{p} \pi_{44}^{k} L \operatorname{og}(G S A V)_{t-l}+\varepsilon_{4 t}
\end{aligned}
$$

\section{Results and Analysis:-}

We discuss the findings of empirical study conducted to examine the relationship between oil revenue (OILREV) and inflation (INFL) growth in Nigeria covering the periods 1970 to 2015. The preliminary data analysis is conducted by displaying the summary statistics of the series involved as well as the corresponding VAR extension applied based on the results from co-integrating relationship and the order of integration of the series in the models. The results for each model were presented and interpreted under the following headings: Test of Stationarity; Cointegration Test; Vector Error Correction Mechanism; Granger Causality; impulse response; Variance Decomposition and Diagnostics Tests. The result and findings are highlighted.

\section{Unit Root Tests:-}

Before conducting the unit root test, we first determined the properties of the time series used. The results derived are presented in table 1 below: 
Table 1:-Properties of Time Series in the INFL Model

\begin{tabular}{|l|l|l|l|}
\hline Variables & $\begin{array}{l}\text { Intercept } \\
(\mathrm{a})\end{array}$ & $\begin{array}{l}\text { Trend } \\
\text { (b) }\end{array}$ & Decision \\
\hline Log (INFL) & $\begin{array}{l}2.79 * * * \\
(0.00)\end{array}$ & $\begin{array}{l}-0.01 \\
(0.00)\end{array}$ & Intercept Only \\
\hline Log (OILREV) & $\begin{array}{l}-0.42^{* *} \\
(0.03)\end{array}$ & $\begin{array}{l}0.23^{* * *} \\
(0.00)\end{array}$ & Intercept \& Trend \\
\hline Log (NSAV) & $0.95 * * *$ & $0.23^{* * *}$ & Intercept \& Trend \\
\hline Log (TGEXP) & $(0.00)$ & $(0.00)$ & $0.20^{*}$ \\
& -0.18 & $(0.00)$ & Trend Only \\
\hline
\end{tabular}

Source: Author's Computation using Eviews9

$*, * *$, and $* * *$ implies significance at $10 \%, 5 \%$, and $1 \%$ respectively.

Hence, in conducting the unit root test, the respective properties were selected in the appropriate boxes in the econometric software (i.e. Eviews 9) used in the data analysis. The ADF unit root test results are presented in table 2 below:

Table 2:-ADF Unit Root Test Results from INFL Model

\begin{tabular}{|c|c|c|c|c|}
\hline \multicolumn{5}{|c|}{ LEVEL } \\
\hline & $\begin{array}{c}\text { ADF Test } \\
\text { Statistics }\end{array}$ & $\begin{array}{c}5 \% \text { Test Critical } \\
\text { Values }\end{array}$ & Decision & Order of Integration \\
\hline Log (INFL) & -3.79 & -2.93 & Stationary & $\mathrm{I}(0)$ \\
\hline Log (OILREV) & -2.12 & -3.51 & Not Stationary & I (0) \\
\hline $\log (\mathrm{NSAV})$ & -2.01 & -3.51 & Not Stationary & $\mathrm{I}(0)$ \\
\hline Log (TGEXP) & 3.28 & -1.95 & Not Stationary & $\mathrm{I}(0)$ \\
\hline \multicolumn{5}{|c|}{ FIRST DIFFERENCE } \\
\hline & $\begin{array}{c}\text { ADF Test } \\
\text { Statistics }\end{array}$ & $\begin{array}{c}5 \% \text { Test Critical } \\
\text { Values }\end{array}$ & Decision & Order of Integration \\
\hline Log (OILREV) & $-7.11 * * *$ & -3.52 & Stationary & $\mathrm{I}(1)$ \\
\hline $\log (\mathrm{NSAV})$ & $-4.76 * * *$ & -3.52 & Stationary & I (1) \\
\hline Log (TGEXP) & $-1.80 * * *$ & -3.52 & Stationary & $\mathrm{I}(1)$ \\
\hline
\end{tabular}

Source: Author's Computation

$*, * *$, and $* * *$ implies significance at $10 \%, 5 \%$, and $1 \%$ respectively.

The results of the stationarity tests for all the variables in the inflation rate model are presented in table 2 . The results presented in the levels test panel show that all the macro econometric time series variables in the inflation model except inflation are all not stationary at levels. This conclusion was reached because the absolute values of the ADF statistics for all the time series except inflation are less than the absolute values of the $5 \%$ test critical values. Moreover, the results presented in first difference panel shows that the other macro econometric time series variables in the inflation model are all stationary at first difference. This conclusion was reached because the absolute values of the ADF statistics for all the three time series are greater than the absolute values of the $5 \%$ test critical values. Hence, we conclude that the time series is a mix of integrated of order zero and order one [i.e. I (0) and I (1)].

Having formally established the stationarity of the macro econometric time series variables in the inflation rate model, it is therefore justified to determine the existence of a long-run relationship between the time series. To determine the existence of a long-run relationship between the time series, the Johansen co-integration test was used as shown in the next section.

Cointegration Test:-

Table 3:-Johansen Test of Cointegration

\begin{tabular}{|c|c|c|}
\hline Null Hypothesis & Trace Stat. & 5\% Crit. Value \\
\hline$r=0$ & $56.29374^{*}$ & 47.86 \\
$r \leq 1$ & 25.01489 & 29.80 \\
$r \leq 2$ & 8.341937 & 15.50 \\
\hline
\end{tabular}




\begin{tabular}{|c|r|r|}
\hline$r \leq 3$ & 2.494519 & 3.84 \\
\hline
\end{tabular}

Source: Author's Computation using Eviews 9

According to Asteriou and Hall (2007), it most desirable that all the time series variables be integrated of the same order before including them in a cointegration test. The authors, however, stated that this is not always the case. And that even in cases where a mix of $I(0), I(1)$ and $I(2)$ variables are present in the model, cointegrating relationships might well exist (Asteriou and Hall, 2007). Our unit root test result shows that the macro econometric time series variables in the inflation rate model are not integrated of the same order. Hence the most desirable case is not evident here. Irrespective of the evidence, we proceeded with the cointegration test and the result presented in table 3. We made use of the trace test statistics from the cointegration test result as the basis for drawing conclusion. The trace statistics shows that the hypothesis of no cointegration, $\mathrm{H}_{0}$, among the variables can be rejected. The result revealed the existence of one cointegrating vector. This conclusion was reached because the trace test statistics for one VAR equation is greater than the $5 \%$ critical values. The existence of one cointegrating equations confirms the existence of a long run relationship among the variables. It also implies that the study can proceed to estimating the vector error correction mechanism (VECM) model.

\section{VECM Inflation Model Estimation:-}

\section{Lag Selection Criteria:-}

The lag selection criterion result presented in table 4 below shows that the FPE, AIC, SC, and HQC suggested 1 lag for the inflation model. The result shows that the selected lag for estimating the VECM inflation model is one. It is reasonable to believe that management of oil revenue and other productive resources would affect the inflation rate in one year. We therefore proceed by estimating VECM with one lag.

Table 4:-Selection Order Criteria Result

\begin{tabular}{|l|c|}
\hline \multicolumn{1}{|c|}{ Criterion } & Lag \\
\hline Final prediction error (FPE) & $\mathbf{1}$ \\
\hline Akaike information criterion (AIC) & $\mathbf{1}$ \\
\hline Schwartz criterion (SC) & $\mathbf{1}$ \\
\hline Hannam-Quinn criterion (HQC) & $\mathbf{1}$ \\
\hline
\end{tabular}

Source: Author's Computation using Eviews 9

Presentation and Interpretation of the Inflation VECM Model:-

Table 5:-Estimated Inflation VECM Model Results

\begin{tabular}{|c|c|c|c|c|}
\hline \multirow{2}{*}{$\begin{array}{c}\text { Elements (i.e. } \\
\text { exogenous) }\end{array}$} & \multicolumn{4}{|c|}{ Equations ( $\mathrm{N}=44$ after adjustment $)$} \\
\hline & $\mathrm{D}(\log (\mathrm{INFL}))$ & $\mathrm{D}(\log ($ OILREV $))$ & $\mathrm{D}(\log (\mathrm{TGEXP}))$ & $\mathrm{D}(\log (\mathrm{NSAV}))$ \\
\hline CointEq1 & $\begin{array}{c}-0.308954 * \\
{[-2.15300]}\end{array}$ & $\begin{array}{c}0.062264 \\
{[0.68601]}\end{array}$ & $\begin{array}{c}0.001867 \\
{[0.03682]}\end{array}$ & $\begin{array}{c}-0.106999 * \\
{[-4.25378]}\end{array}$ \\
\hline $\mathrm{D}(\log (\operatorname{INFL}(-1)))$ & $\begin{array}{c}0.036128 \\
{[0.21395]}\end{array}$ & $\begin{array}{c}0.055198 \\
{[0.51681]}\end{array}$ & $\begin{array}{c}0.072961 \\
{[1.22282]}\end{array}$ & $\begin{array}{c}0.063340 \\
{[2.13988]}\end{array}$ \\
\hline $\mathrm{D}(\log (\operatorname{OILREV}(-1)))$ & $\begin{array}{l}-0.340387 \\
{[1.09752]}\end{array}$ & $\begin{array}{c}0.055419 \\
{[0.28251]}\end{array}$ & $\begin{array}{l}0.219553 \\
{[2.00346]}\end{array}$ & $\begin{array}{l}-0.040154 \\
{[0.73860]}\end{array}$ \\
\hline $\mathrm{D}(\log (\operatorname{TGEXP}(-1)))$ & $\begin{array}{c}0.157211 \\
{[0.31772]} \\
\end{array}$ & $\begin{array}{l}-0.069286 \\
{[0.22139]} \\
\end{array}$ & $\begin{array}{l}-0.319490 \\
{[1.82738]} \\
\end{array}$ & $\begin{array}{c}0.178290 \\
{[2.05559]} \\
\end{array}$ \\
\hline $\mathrm{D}(\log (\mathrm{NSAV}(-1)))$ & $\begin{array}{c}1.102096 \\
{[1.15363]}\end{array}$ & $\begin{array}{l}-0.500541 \\
{[0.82838]}\end{array}$ & $\begin{array}{c}0.321857 \\
{[0.95349]}\end{array}$ & $\begin{array}{l}-0.174648 \\
{[1.04294]} \\
\end{array}$ \\
\hline $\mathrm{C}$ & $\begin{array}{l}-0.223118 \\
{[0.91224]}\end{array}$ & $\begin{array}{l}0.322581 \\
{[2.08523]}\end{array}$ & $\begin{array}{c}0.124699 \\
{[1.44292]}\end{array}$ & $\begin{array}{c}0.252096 \\
{[5.88010]}\end{array}$ \\
\hline R-squared & 0.247061 & 0.076985 & 0.232721 & 0.410916 \\
\hline F-statistics & 2.493779 & 0.633882 & 2.305139 & 5.301380 \\
\hline
\end{tabular}

Source: Author's Computation using Eviews 9

The estimated INFL VECM Model results are presented in table 4.5. The error correction coefficients (i.e. -0.31 and -0.11) for inflation and gross national saving equations are statistically significant at the $5 \%$ level since the $t-$ 
statistics are greater than 2.00. This implies that a yearly adjustment for inflation and gross national savings will be $0.31 \%$ and $0.11 \%$ of deviation from their cointegrating values. This implies that if a long-run relationship is broken, inflation and gross national savings will react against the error with adjustable speed of $30.90 \%$.

The coefficient (i.e. -0.34) and t-statistics $(1.10<2.00)$ of $\mathrm{D}(\log (O I L R E V(-1)))$ shows that one period lag of oil revenue had a negative but an insignificant impact on inflation. Secondly, the coefficient (i.e. 0.15) and t-statistics (i.e. $0.32<2.00)$ of $\mathrm{D}(\log (\operatorname{TGEXP}(-1)))$ shows that one period lag of total government expenditure had a positive but an insignificant impact on inflation. Lastly, the coefficient (i.e. 1.10) and t-statistics $(1.15<2.00)$ of $\mathrm{D}(\log (N S A V(-1)))$ show that one period lag of gross national savings had a positive but an insignificant impact on inflation during the study period.

A look at the coefficient (i.e. 0.22) and t-statistics $(2.003>2.00)$ of the oil revenue in the $\mathrm{D}(\log (T G E X P))$ equation show that one period lag of oil revenue had a significant impact on government total expenditure during a current year.

The explanatory power of the inflation equation is very weak with an R-squared of 0.2471 . This implies that $24.71 \%$ variation in inflation was explained by the explanatory variables in the inflation equation. Moreover, the F-statistics of 2.49 was also less than the F-critical of 4.00; implying that the explanatory variables did not also combine significantly to predict inflation during the period of study.

The analysis of the estimated VECM INFL model shows that, though oil revenue had a significant impact on government spending, a significant complete transmission mechanism was not observed from oil revenue to government total expenditure and then to inflation. This implies that oil revenue oil did not have the desired impact on inflation between 1970 and 2015.

Granger Causality Test for Inflation Model:-

Table 6:-Granger Causality Test Results from Inflation Model

\begin{tabular}{|c|c|c|c|c|c|}
\hline \multirow{2}{*}{$\begin{array}{c}\text { Dependent } \\
\text { Variables }\end{array}$} & Log(INFL) & Log(OILREV) & Log(TGEXP) & Log(NSAV) & Joint Causality \\
\cline { 2 - 6 } & & & 0.100948 & 1.330870 & 3.612491 \\
Log(INFL) & - & 1.204539 & $(0.7507)$ & $(0.2487)$ & $(0.3065)$ \\
\hline Log(OILREV) & 0.267096 & $(0.2724)$ & 0.049012 & 0.686212 & 1.184298 \\
& $(0.6053)$ & - & $(0.8248)$ & $(0.4075)$ & $(0.7568)$ \\
\hline Log(TGEXP) & 1.495291 & 4.013855 & & 0.909145 & 9.400253 \\
& $(0.2214)$ & $(0.0451)$ & - & $(0.3403)$ & $(0.0244)$ \\
\hline Log(NSAV) & 4.579093 & 0.545528 & 4.225460 & & 7.197773 \\
& $(0.0324)$ & $(0.4602)$ & $(0.0398)$ & - & $(0.0659)$ \\
\hline
\end{tabular}

Source: Author's Computation using Eviews 9

Table 6 above shows the granger causality test (using the chi2 statistics) result based on the estimated INFL VECM model. The table provided individual and joint granger causality test results and the following was observed:

1. The p-value of the chi2 statistics of $\log (O I L R E V)$ in the estimated $\log (I N F L)$ equation is 0.27 . This result shows that $\log (O I L R E V)$ is not significant at 5\%. Hence, the null hypothesis of no causality cannot be rejected. The result implies that oil revenue did not Granger cause inflation in Nigeria during the period of study.

2. The p-value of the chi2 statistics of $\log (T G E X P)$ in the estimated $\log (I N F L)$ model is 0.75 . This result shows that $\log (T G E X P)$ is also not significant at $5 \%$. Hence, the null hypothesis of no causality cannot be rejected. The result implies that government total expenditure did not Granger cause inflation in Nigeria during the period of study.

3. The p-value of the chi2 statistics of $\log (N S A V)$ in the estimated $\log (I N F L)$ model is 0.25 . This result shows that $\log (N S A V)$ is not significant at $5 \%$. Hence, the null hypothesis of no causality cannot be rejected. The result implies that gross national savings did not Granger cause inflation in Nigeria during the period of study.

4. The p-value of the chi2 statistics of joint causality of $\log (O I L R E V), \log (T G E X P)$ and $\log (N S A V)$ in the estimated $\log (I N F L)$ model is 0.31 . This result shows that $\log (O I L R E V), \log (T G E X P)$ and $\log (N S A V)$ did not combine significantly to granger cause inflation in Nigeria during the period of study. 
5. The p-value of the chi2 statistics of $\log (O I L R E V)$ in the estimated $\log (T G E X P)$ equations is 0.05 . This result shows that oil revenue granger caused government total expenditure in Nigeria during the period of study.

\section{Impulse Response Function (IRF) based on the INFL Model:-}

Figure 1 shows the graph of the response of inflation to a shock in oil revenue, government total expenditure and gross national savings. The first graph represents the response of inflation to one standard deviation shock in oil revenue. The blue line in the graph represents the impulse response function of inflation to shock in oil revenue. It was observed that from $t=1$ ( $t$ is in year units) the response was positive till when $t=10$. A unit positive standard deviation shock to oil revenue will lead to a positive response from inflation. The effect oil revenue on inflation will be positive from the first year till the tenth year.

The second graph in figure 1 represents the response of inflation to one standard deviation shock in government total expenditure. It was observed that from $t=1$ ( $t$ is in year units) the response was negative till when $t=4$, but was stable from $\mathrm{t}=5$ to 10 . A unit standard deviation shock to government total expenditure will lead to a negative response from inflation. The effect of government total expenditure on inflation will be negative from the first year till the tenth year.

The last graph in figure 1 represents the response of inflation to one standard deviation shock in gross national savings. It was observed that from $t=1$ ( $t$ is in year units) the response was positive till when $t=2$ and remained negative till when $t=10$. A unit standard deviation shock to gross national savings will lead to a positive response from inflation for some years and continued to be negative for eight years. The effect of gross national savings on inflation will be positive from the first year to the second year and then remained negative till the tenth year. 
Figure 1:-IRF Graphs Showing Response of INFL to Shock in the Explanatory Variables Response to Cholesky One S.D. Innovations

Response of LOG(INFL) to LOG(OILREV)

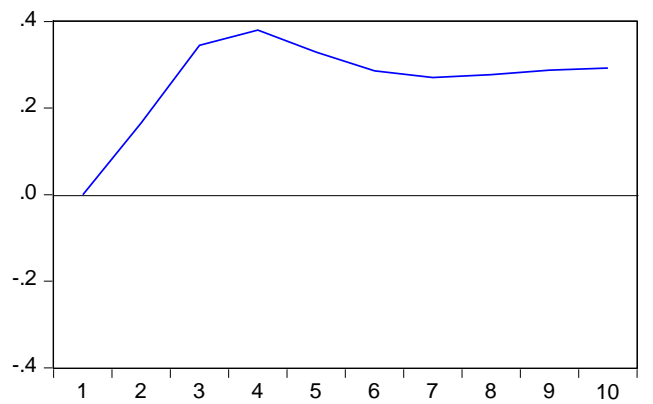

Response of LOG(INFL) to LOG(TGEXP)

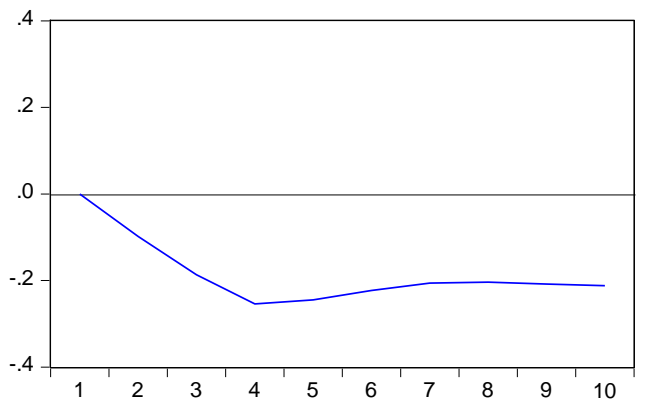

Response of LOG(INFL) to LOG(NSAV)

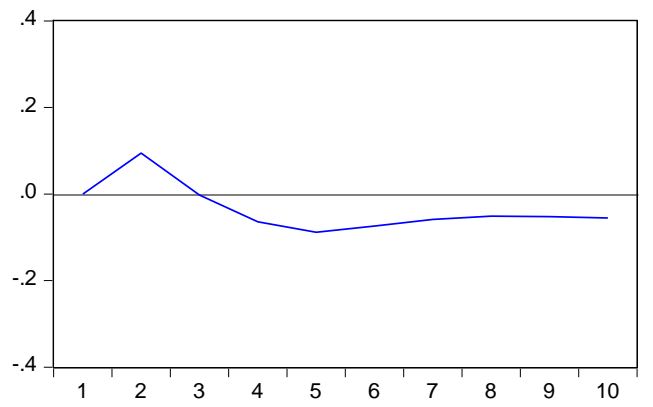

Forecast Error Variance Decomposition (FEVD):-

The results of the FEVD are presented in table 7. From the forecast error variance decomposition of the inflation column of the table, it was observed that a shock in oil revenue will account for an average of $18.90 \%$ variation in inflation during a 10-year period. Moreover, a shock in government total expenditure and gross national savings will account for an average of $8.40 \%$ and $1.07 \%$ variation in inflation during a 10-year period respectively.

The forecast error variance decomposition of government total expenditure and gross national savings columns in table 7 shows that a shock in oil revenue will account for an average of $1.70 \%$ and $67.06 \%$ variation in government total expenditure and gross national savings respectively during a 10-year period.

The analysis of the FEVD result above shows that while oil revenue and government total expenditure will account more for variation in inflation during a 10-year period; inflation and oil revenue will account more for variation in government total expenditure and gross national savings respectively during a 10 -year period. This shows that managing oil revenue for the purpose of stabilizing the general price level in Nigeria should be the focus of the government. 
Table 7:-Forecast Error Variance Decomposition Result

\begin{tabular}{|c|c|c|c|c|c|c|c|c|c|}
\hline & \multicolumn{3}{|c|}{$\begin{array}{c}\text { Variance Decomposition of } \\
\text { INFL }\end{array}$} & \multicolumn{3}{|c|}{$\begin{array}{c}\text { Variance Decomposition of } \\
\text { TGEX }\end{array}$} & \multicolumn{3}{|c|}{$\begin{array}{l}\text { Variance Decomposition of } \\
\text { NSAV }\end{array}$} \\
\hline Period & OILREV & TGEXP & NSAV & OILREV & INFL & NSAV & INFL & OILREV & TGEXP \\
\hline 1. & 0 & 0 & 0 & 0.509505 & 22.59523 & 0 & 0.075887 & 28.57829 & 0.428035 \\
\hline 2. & 3.56325 & 1.25775 & 1.154337 & 2.704433 & 41.15434 & 0.879898 & 0.650733 & 57.09244 & 0.223063 \\
\hline 3. & 13.4988 & 4.1183 & 0.818758 & 2.396594 & 46.49672 & 0.660532 & 2.910392 & 68.13848 & 2.382615 \\
\hline 4. & 20.59938 & 7.736694 & 0.924436 & 2.048904 & 51.62573 & 0.564993 & 5.099972 & 578 & 3.55592 \\
\hline 5. & 23.54222 & 9.977641 & 1.230865 & 1.788712 & 54.3172 & 0.460383 & 6.257143 & 72.83617 & 4.179377 \\
\hline 6. & 24.59211 & 11.19399 & 1.349944 & 1.640354 & 55.9731 & 0.398179 & 6.774687 & 73.55761 & 4.339191 \\
\hline 7. & 25.05845 & 11.81587 & 1.350256 & 1.555893 & 56.89216 & 0.355676 & 6.966902 & 74.09058 & 4.368847 \\
\hline 8. & 25.51415 & 12.24629 & 1.312204 & 1.504447 & 57.57005 & 0.328881 & 7.070367 & 74.55368 & 4.373427 \\
\hline 9. & 26.04522 & 12.63282 & 1.283269 & 1.462966 & 58.11917 & 0.307898 & 7.168409 & 74.94476 & 4.400235 \\
\hline 10 & 26.56583 & 13.0023 & 1.270864 & 1.425966 & 58.59991 & 0.290549 & 7.274857 & 75.26109 & 4.438833 \\
\hline Average & 18.8979 & 8.3982 & 1.0695 & 1.7038 & 50.3344 & 0.4247 & 5.0249 & 67.0649 & 3.2690 \\
\hline
\end{tabular}

Source: Author's Computation Using Eviews 9

Post Estimation Tests:-

Conducting diagnostics or post estimation is necessary to enable us figure out the adequacy of the model and other results. Passing the tests confirms the adequacy and usefulness of the model.

\section{Serial Correlation Test:-}

The first test conducted is the Lagrange-multiplier (LM) test for serial correlation in the residuals. The LM test of autocorrelation result presented in table 8 shows that we cannot reject the null hypothesis of no serial correlation in the residuals at all levels of significance and all the two-lag orders.

Table 8:-VEC Residual Serial Correlation LM Test

\begin{tabular}{|c|c|c|}
\hline Lags & LM-Stat & Prob>chi2 \\
\hline 1 & 13.43 & 0.64 \\
2 & 17.51 & 0.35 \\
\hline \multicolumn{2}{|c|}{ H0: no serial correlation at lag order $\mathrm{h}$} \\
\hline
\end{tabular}

Source: Author's Computation using Eviews 9

\section{Normality Test:-}

The text for the normality of the residuals was done through the Jarque-Bera test. Table 9 shows that we cannot reject the null hypothesis of normally distribution of residuals for all the four components and the joint. The model therefore passed the normality test. It therefore implies that the residuals are normally distributed.

Table 9:-Jarque-Berra Normality Test Result

\begin{tabular}{|c|c|c|c|}
\hline Components & Jarque-Berra & Df & Prob>chi2 \\
\hline 1 & 0.109031 & 2 & 0.9469 \\
2 & 0.138493 & 2 & 0.9331 \\
3 & 5.875676 & 2 & 0.0530 \\
4 & 2.258773 & 2 & 0.3232 \\
Joint & 8.381972 & 8 & 0.3971 \\
\hline
\end{tabular}

Source: Author's Computation using Eviews 9

Heteroscedasticity Test:-

Table 10:-Residual Heteroscedasticity Tests (Includes Cross Terms) for INFL Model

\begin{tabular}{|c|c|c|}
\hline \multicolumn{2}{|c|}{ Joint Test } \\
\hline Chi-square & Df & Prob. \\
\hline 189.26 & 200 & 0.70 \\
\hline
\end{tabular}

Source: Author's Computation using Eviews 9 
The null cannot be rejected since the p-value of the joint test is greater than 0.05 . We therefore conclude that the specified model did not suffer from heteroscedasticity problem. The model satisfied the homoscedasticity assumption. Hence the estimates passed this test too.

\section{Conclusion and Recommendation:-}

This empirical study is aimed to determine the relationship between oil revenue and inflation in Nigeria. The paper employs a vector autoregressive model (VAR) techniques; Unit root test, Cointegration test, Granger causality tests, Impulse response function (IRF) and forecast error variance decomposition (FEVD). The impulse response result shows that a unit positive standard deviation shock to oil revenue will lead to a positive response from inflation from the first year till the tenth year. Moreover, the controlling variables show a negative response from year one to the tenth year. The variance decomposition result shows that a shock in oil revenue will account for an average of $18.90 \%$ variation in inflation, moreover, a shock in government total expenditure and gross national savings will account for an average of $8.40 \%$ and $1.07 \%$ variation in inflation during a 10 -year period respectively. This study concludes that oil revenue has a positive impact on inflation, whereas government expenditure and national savings would reduce inflation growth. This suggests that fiscal policy in the form of increase government expenditure and savings should be implemented to stabilize the economy and moderate inflation.

\section{References:-}

1. Akinifesi, E. O (1984). Inflation in Nigeria: Causes, Consequences and Control CBN Bullion, Silver Jubilee Edition vol. July.

2. Apere, T. G. O. (2017).Crude Oil Price Fluctuation and Inflation in Nigeria. Advances in Social Sciences Research Journal, Vol 4(3) 190-200.Copyright Society for Science and Education, United Kingdom 190

3. Arndt, H. W (1985). The Origins of Structuralism. World Development 13.2 (1985): 151-159. '

4. Barro, R. J (1995): Inflation and Economic Growth. National Bureau of Economic Research (NBER) working paper no. 5326 (October).

5. Brini, R., Haterm, J and Arafet, F (2016). Economic impacts of oil price shocks on inflation and real exchange rate: Evidence from selected MENA countries. 15th International Conference Middle East Economic. Topics in Middle Eastern and African Economies Vol. 18, Issue No. 2, September 2016

6. Campos, R. 0 (1961). Two Views of Inflation in Latin America. Latin American Issues; Essays and Comments. Ed. A. O. Hirschman. New York, 1961. 69-79.

7. CBN (1974). Origin and Development of Inflationary Trend in African Countries (Impact on Their Growth). CBN Economic and Financial Review, Vol. 12 No 2 December

8. CBN (1996). Money Supply, Inflation and the Nigerian Economy Bullion Publication of CBN, Vol. 21 No 3 July/September.

9. CBN (2015). CBN Statistical Bulleting. Vol. 14 December.

10. CBN (2017). Central Bank of Nigeria Quarterly Statistical Bulletin Vol 6, No 4, December 2017 Statistical Tables Published

11. Chenery, H. B (1975). The Structuralist Approach to Development Policy. The American Economic Review 65.2 (1975): 310-316.

12. Dickey, D. A and W. A Fuller (1979). Distribution of the Estimators for Auto regressive time series with a unit Root. Journal of American Statistical Association vol. 74. pp 427 - 431.

13. Fashoyin, T. (1986). Incomes and Inflation in Nigeria. Longman Publishers Ltd, New York

14. Fisher, I (1911). The Purchasing Power of Money. New York: Macmillan. Reprinted in The Works of Irving Fisher, Vol. 4, 1997

15. Friedman, M (1963). Inflation: Causes and Consequences. New York: Asia Publishing House, 1963.

16. Granger, C. W (1977). The Time Series Approach to Econometric Model Building. In C.A. Sims (ed), New Methods in Business Cycle Research. Minneapolis: Federal Reserve Bank of Minneapolis.

17. Hamilton, E. J. (1934). American Treasures and the Price Revolution in Spain, 1501 - 1650, Harvard Economic Studies, 43 Cambridge, Massachusetts: Harvard University Press.

18. Iyoha, M (2002). Budget of Economic Growth and Development. Bullion Publication of CBN, Vol. 26 No.2 April/June

19. Jhingan, M. L (2002). Macroeconomic Theory.10th Edition, Vrinda Publications Ltd, New Delhi.

20. Kamyar, R (2013). The Relationship between Inflation Rate, Oil Revenue and Taxation in IRAN: Based OLS Methodology. Journal of Economics and Sustainable Development www.iiste.org. ISSN 2222-1700 (Paper) ISSN 2222-2855 (Online).Vol.4, No.19, 2013 
21. Kamyar, R and Yousef, R (2015). The Granger Causality of Inflation Rate, Oil Revenue and Taxation in Iran. International Journal of Economics, Commerce and Management, United Kingdom Vol. III, Issue 10, October 2015

22. Makin, J. (2010), Bernauke Battles U. S Deflation Threat. AEJ. Journal of Economics and Sustainable Development www.iiste.org ISSN 2222-1700 (Paper) ISSN 2222-2855 (Online) Vol.6, No.6, 2015

23. McCallum, B. T. (1987). Inflation: Theory and Evidence, New York, the American National Bureau of Economic Research, Working Paper No. 2312, 1987.

24. Nwanna, I.O., Eyedayi, A.M. (2016). Impact of crude oil price volatility on economic growth in Nigeria (19802014).IOSR Journal of Business and Management (IOSR-JBM), 18(6), 10-19.

25. Noyola, V. J (1956). Economic development and inflation in Mexico and other Latin American countries. Economic Investigation 16.4 (1956): 603-649.

26. Olivera, J. H. G (1964). On Structural Inflation and Latin American Structuralism. Oxford Economic Papers 16.3 (1964): 321-332.

27. Ojonye, S., M (2015). The Dynamics of Inflation and its Impact on the Nigerian Economy: 1960 - 2012: An Empirical Analysis. Journal of Economics and Sustainable Development www.iiste.org ISSN 2222-1700 (Paper) ISSN 2222-2855 (Online) Vol.6, No.6, 2015

28. Olomola, P.A., Adejumo, A.V. (2006). Oil price shock and macroeconomic activities in Nigeria. International Research Journal of Finance and Economics, 3, 28-34.

29. OPEC (1984). OPEC Annual Statistical Bulletin. 17, A-1010 Vienna, Austria www.opec.org Organization of the Petroleum Exporting Countries

30. Oriakhi, D., E and Iyoha, D., O, (2013). Oil Price Volatility and its Consequences on the Growth of the Nigerian Economy: An Examination (1970-2010). Asian Economic and Financial Review, 2013, 3(5):683702683

31. Osakwe J. O. (1983). Government Expenditure, Money Supply and Prices, 1970 - 1980. CBN Economic and Financial Review, Vol. 21 No 2 June

32. Ricardo, D (1817). Principles of Political Economy and Taxation, London, Murrary Publication, 1817.

33. Sunkel, 0 (1958). Chilean inflation: a heterodox approach. The Economic Trimester, Vol. 25.4 (1958); English translation in International Economic Papers No. 10.

34. Tural, K., Nigar, J., Heyran, A and Salman, H (2016). Oil Price Pass-Through into Inflation: The Evidence from Oil Exporting Countries. Graduate institute.ch/files/live/sites/iheid/files/sites/bcc/.../IHEIDWP24_2015.pdf

35. Umar, M., G, Aliyu, I., A and Ahmad, M (2017). Oil Price Fluctuations and Economic Growth in Nigeria: (Evidence from Granger Causality Test). Australasian Journal of Social Science, ISSN 2251-3205, DOI: 10.3923/aujss.2017.1.16

36. Wesley, C. M (1896). Quantity Theory on the Value of Money. The Journal of Political Economy, retrieved online, Mar. 1896, http://www.jstor.org/stable/1817857 